\title{
PENGARUH DUKUNGAN ORGANISASI TERHADAP KOMITMEN ORGANISASIONAL DENGAN PSYCHOLOGICAL CONTRACT SEBAGAI VARIABEL MODERASI
}

\author{
Fifi Prananda ${ }^{1}$ \\ I Gede Riana ${ }^{2}$ \\ ${ }^{1,2}$ Fakultas Ekonomi dan Bisnis Universitas Udayana, Bali, Indonesia \\ email: fifiprananda@yahoo.co.id
}

\begin{abstract}
ABSTRAK
Tujuan dari penelitian ini adalah untuk menguji pengaruh dukungan organisasi terhadap komitmen organisasional dengan psychological contract sebagai variabel moderasi. Penelitian ini dilakukan pada dua tempat usaha yang bergerak dibidang yang sama yaitu Wisata Bahari Adventure Tanjung Benoa, Bali. Jumlah sampel dalam penelitian ini adalah sebanyak 100 orang responden, dimana dengan mengambil seluruh populasi di dua perusahaan tersebut dengan menggunakan teknik sampling jenuh. Pengumpulan data diperoleh dari hasil penyebaran kousioner secara langsung kepada karyawan. Analisis penelitian data menggunakan Moderated Regression Analysis (MRA). Hasil penelitian ini menyatakan dukungan organisasi berpengaruh positif signifikan terhadap komitmen organisasional, psychological corntact berpengaruh positif signifikan terhadap komitmen organisasional, dan dukungan organisasi berpengaruh terhadap komitmen organisasional dengan psychological contract memperkuat kedua variabel tersebut.

Kata kunci: Dukungan organisasi, Komitmen organisasional, Psychological contract
\end{abstract}

\begin{abstract}
The purpose of this study was to examine the effect of organizational support on organizational commitment with psychological contracts as a moderating variable. This research was conducted at two business places that are engaged in the same field, namely Maritime Tourism Adventure Tanjung Benoa, Bali. The number of samples in this study were 100 respondents, where by taking the entire population in the two companies using saturated sampling techniques. Data collection is obtained from the results of distributing questionnaires directly to employees. Analysis of research data using Moderated Regression Analysis (MRA). The results of this study stated that organizational support had a significant positive effect on organizational commitment, psychological corntact had a significant positive effect on organizational commitment, and organizational support had an effect on organizational commitment with psychological contracts to strengthen both variables.
\end{abstract}

Keywords: Organizational Support, Organizational Commitment, Psychological Contract 


\section{PENDAHULUAN}

Sumber daya manusia yang berkualitas sangat dibutuhkan di daerah Bali, dimana Bali merupakan salah satu tujuan wisatawan di seluruh dunia. Memiliki sumber daya manusia yang berkualitas adalah suatu hal yang penting dalam penentuan keberhasilan suatu perusahaan, (Widarianti dan Sintaasih, 2019).Wisata bahari memiliki prospek yang cukup baik serta melaksanakan program pemerintah untuk tetap menjaga kelestarian dan keindahan di Bali.

Tanjung benoa Bali adalah desa yang terkenal dengan wisata baharinya ada beberapa perusahan yang bergerak dalam bidang wisata bahari di tanjung benoa Bali. Namun hanya dua perusahan yang dapat memberikan datanya, dua perusahaan ini sama-sama bergerak dalam bidang tersebut, selain itu kedua perusahaan ini juga memanfaatkan keindahan bawah laut dalam menjalankan perusahaannya. Serta didukung sumber daya alamnya, peran sumber daya manusia juga sangat penting dalam hal ini adalah karyawan yang melaksanakan kegiatan dalam perusahaan untuk mencapai visi misi tersebut, perusahaan harus memiliki sumber daya manusia yang berkualitas, kompeten dan memiliki komitmen organisasional yang tinggi.

Komitmen organisasional merupakan faktor yang mempengaruhi diri individu pada suatu organisasi (Guest, 2016). Komitmen pada organisasi didefinisikan sebagai suatu keadaan dimana seorang karyawan memihak pada suatu organisasi tertentu dan tujuan-tujuannya, serta berniat memelihara keanggotaan dalam organisasi itu (Allen and Brady 2008). Karyawan dianggap berkomitmen untuk sebuah organisasi jika mereka rela melanjutkan hubungan mereka dengan organisasi dan mengabdikan diri untuk mencapai tujuan organisasi (Dewi dan Rahyuda, 2015)

Dukungan organisasi dapat didefinisikan sebagai persepsi karyawan mengenai sejauh mana organisasi memberi dukungan kepada karyawan dan sejauh mana kesiapan organisasi dalam memberikan bantuan saat di butuhkan (Colakoglu, 2010). Karyawan yang memiliki dukungan organisasi merasa bahwa organisasi bersedia untuk membantu karyawannya, jika karyawannya mengalami suatu masalah di dalam organisasi, dengan demikian karyawan akan memberikan umpan balik terhadap organisasinya dengan cara meningkatkan prestasi kerja dan meningkatkan kerja sama antar karyawan (Pathak, 2012). Menurut (Wayne, 2002) juga menekankan dukungan organisasi adalah keyakinan yang dikembangkan oleh karyawan mengenai sejauh mana organisasi menghargai mereka (pegawai) dilihat dari penghargaan organisasi terhadap kontribusi mereka dan perhatian organisasi terhadap kehidupan mereka.

(Fung, N.S., 2012) menyatakan bahwa teori pertukaran sosial merupakan pandangan karyawan ketika mereka telah diperlakukan dengan baik oleh organisasi, mereka akan cenderung untuk bersikap dan berperilaku lebih positif pada organisasi. Para karyawan lebih cenderung menganggap diri mereka berada dalam hubungan pertukaran sosial dengan para atasan mereka karena perlakuan etis yang mereka terima dan kepercayaan yang mereka rasakan, ketika karyawan merasa bahwa atasan mereka memiliki minat terbaik di hati dan peduli, mereka cenderung untuk membalas dengan meningkatkan kinerjanya (Guest, 2016). Psychological Contract adalah kontrak tidak tertulis yang timbul dalam diri 
karyawan yang muncul ketika karyawan menganggap kontribusi mereka untuk organisasi membuahkan kewajiban yang diharus dibalas oleh organisasi. (Hardiyanto R., 2011) menjelaskan bahwa psychological contract mewakili bagaimana orang-orang menunjukan janji dan komitmen, kedua belah pihak dalam hubungannya, maka suatu organisasi akan berjalan seperti yang diharapkan. Adapun hasil pra-survei yang dilakukan di dua perusahan yang berjumlah 20 karyawan, sebagai berikut.

Tabel 1.

Hasil Pra-Survei Data Komitmen Organisasional

\begin{tabular}{|c|c|c|c|c|c|c|}
\hline No & Pernyataan & STS & TS & CS & $\mathbf{S}$ & SS \\
\hline 1. & $\begin{array}{l}\text { Saya mempunyai rasa memiliki yang kuat } \\
\text { terhadap organisasi. }\end{array}$ & - & 15 & 2 & 3 & - \\
\hline 2. & $\begin{array}{l}\text { Saya bertanggung jawab atas keberhasilan } \\
\text { organisasi. }\end{array}$ & - & 15 & 1 & 4 & - \\
\hline 3. & $\begin{array}{l}\text { Saya senang menghabiskan sisa karir saya di } \\
\text { perusahaan ini. }\end{array}$ & - & 10 & 7 & 3 & - \\
\hline 4. & $\begin{array}{l}\text { Saya merasa perusahaan banyak berjasa bagi } \\
\text { saya. }\end{array}$ & - & 12 & 7 & 1 & - \\
\hline 5. & $\begin{array}{l}\text { Saya berupaya optimal untuk memberikan hasil } \\
\text { pemikiran untuk memajukan organisasi. }\end{array}$ & - & 8 & - & 12 & - \\
\hline \multirow[t]{2}{*}{6.} & $\begin{array}{l}\text { Akan sulit bagi saya untuk meninggalkan } \\
\text { perusahaan }\end{array}$ & - & 15 & - & 5 & - \\
\hline & Total & & 75 & 17 & 28 & \\
\hline
\end{tabular}

Sumber: Data Diolah, 2019

Berdasarkan hasil wawancara pada perusahaan tersebut, dimana terdapat permasalahan yang berindikasi menimbulkan rendahnya komitmen karyawan dalam berorganisasi. Hal tersebut terlihat dari lebih banyak karyawan yang menjawab tidak setuju pada pertanyaan yang diajukan mengenai komitmen organisasional. Hasil wawancara dapat diduga bahwa karyawan mempunyai rasa memiliki dan kesetian yang rendah terhadap perusahaan sehingga karyawan merasa tidak ingin menghabiskan karir dan tidak akan sulit maupun merasa rugi jika meninggalkan perusahaan, hal ini mengakibatkan berpindahnya dari satu perusahaan ke perusahaan lain dianggap etis oleh karyawan, namun ada hal lain yang dikeluhkan oleh karyawan yaitu mengenai karyawan tidak bisa naik jabatan ataupun perkembangan karirnya tidak sejalan dengan kemampuan mereka, dapat disimpulkan bahwa komitmen karyawan redah di dalam perusahaan.

Faktor yang dapat mempengaruhi tinggi rendahnya komitmen organisasi karyawan juga ada dukungan organisasi, (Millward, 1998) menekankan juga bahwa dalam perspektif jaringan sosial, dukungan organisasi, pemimpin dan rekan kerja, secara emosional merupakan aspek yang penting, jaringan sosial yang kuat akan menimbulkan keterikatan yang kuat antara karyawan dan organisasi, sehingga akan menimbulkan solidaritas yang tinggi. Dukungan organisasi sebagai persepsi karyawan pada lingkungan kerja dan kondisi yang ditetapkan oleh organisasi sebagai bentuk kesadaran terhadap organisasi, apresiasi dan upaya untuk memfasilitasi kontribusi karyawan (Agustiningrum, 2016). Wisata bahari tanjung benoa nusa dua, Bali terdapat indikasi kurang adanya dukungan organisasi antara 
lain, organisasi kurang mengapresiasi pekerjaan yang telah di selesaikan oleh karyawan yaitu berupa ucapan terimakasi atau pun berupa bonus. Karyawan yang telah berkerja dengan baik dan dalam jangka waktu yang cukup lama tidak di promosikan untuk naik jabatan, sehingga akan menimbulkan rasa tidak memiliki terhadap perusahan.

(Hardiyanto, 2011) menyatakan psychological contract dalam suatu perusahaan adalah hal yang penting untuk menghasilkan komitmen yang baik antara karyawan dan perusahaan, psychological contract merupakan suatu kumpulan-kumpulan harapan tidak tertulis yang ada dalam diri setiap individu. Kunci dari psychological contract adalah mutualitas di antara individu dengan individu, maupun individu dengan perusahaan (Tsui, 2013). Mutualitas hanya terjadi dan muncul apabila masing-masing dari pihak yang berkepentingan atau bersangkutan memiliki tujuan dan yakin untuk dapat dicapai, serta menyeimbangkan psychological contract pada kedua belah pihak bahwa mutualitas dapat menghasilkan sesuatu yang bernilai (Anoraga, 2005).

Dukungan organisasi juga memperkuat penilaian positif karyawan baik secara kognitif maupun emosional terhadap organisasi (Mullen, 2006). (Karagonlar, 2016) menyatakan bahwa dukungan organisasi menunjukkan kualitas hubungan karyawan dengan organisasi yang mengetahui bagaimana karyawan mempercayai kontribusi yang diberikan oleh organisasi. Karyawan yang mendapatkan apa yang mereka presepsikan terhadap organisasinya, maka karyawan akan tetap tinggal di dalam sebuah organisasi, (Colakoglu, 2010).

(Eisenberger, 2002) menyatakan bahwa dukungan organisasi menunjukkan kualitas hubungan karyawan dengan organisasi yang mengetahui bagaimana karyawan mempercayai kontribusi yang diberikan oleh organisasi. Hasil penelitian ini didukung oleh penelitian yang dilakukan oleh (Dewi dan Rahyuda, 2015), (Nazir dan Islam, 2017), (Karagonlar, 2016), (Sharma \& Dhar 2016), (Ahmed, 2015), memperoleh hasil bahwa dukungan organisasi berpengaruh positif signifikan terhadap komitmen organisasi, hal ini ditunjukkan dari adanya persepsi dukungan organisasi karyawan sehingga karyawan berkeyakinan tentang nilainya dalam berorganisasi sehingga berdampak dapat memberikan kontribusi untuk organisasi. Berdasarkan penelitian sebelumnya dapat dirumuskan hipotesis sebagai berikut:

$\mathrm{H}_{1}$ : Dukungan organisasi berpengaruh positif dan signifikan terhadap komitmen organisasional

(Griffin, 2013) menyatakan bahawa psychological contract adalah serangkaian ekspektasi yang dimiliki seorang individu menyangkut apa yang akan dia kontribusikan untuk organisasi. Psychological Contract dalam suatu organisasi adalah hal yang penting untuk menghasilkan komitmen yang baik antara pegawai dan organisasi (Liao, 2005). Kunci dari kontrak psikologis adalah mutualitas diantara, individu dengan organisasi, mutualitas ini muncul dan hanya terjadi jika masing-masing dari pihak memiliki kepentingan yang ingin dicapainya (Coyle, 2000). Kunci dari kontrak psikologis adalah mutualitas diantara individu dengan individu, maupun individu dengan organisasi, mutualitas ini muncul dan hanya terjadi jika masing-masing dari pihak yang berkepentingan memiliki tujuan yang ingin dicapainya (Coyle, 2000). 
Hasil penelitian ini senada dengan (Low, 2016), (Guest, 2016), (Karagonlar,2016), (Rayton, B.A., \& Yalabik, 2014) menyatakan bahwa psychological contract berpengaruh positif signifikan terhadap komitmen organisasional, dimana jika seorang karyawan merasa bahwa psychological contract terpenuhi maka karyawan merasa bahwa mereka dihargai oleh perusahaan. Akan cendrung berada tetap didalam organisasi dan berkomitmen terhadap perusahaan. Berdasarkan penelitian sebelumnya dapat dirumuskan hipotesis sebagai berikut:

$\mathrm{H}_{2}$ : psychological contract berpengaruh positif dan signifikan terhadap komitmen organisasional.

Psychological Contract merupakan bentuk kontribusi dari individu terhadap organisasi seperti upaya, keahlian, kemampuan, waktu, kesetiaan, untuk organisasi sebagai bentuk imbalan dan kontribusi (Anggraeni, 2017). Organisasi memberikan insentif kepada karyawan berupa gaji, dan peluang pengembangan karir sebagai balas jasa (Rhoades, 2001). Dapat dilihat terjadi hubungan timbal balik antara karyawan dan organisasi, karyawan berkontribusi terhadap organisasi dan organisasi membalasnya dengan imbalan yang setimpal (Blau, 2007).

Penelitian yang dilakukan oleh (Maria, 2016), (Jabeen f., 2015), (Kiazad, 2014), (Van den, 2015), (Low, 2016) bahwa psychological contract secara positif memodesi dukungan organisasi terhadap komitmen organisasional, yang menjelaskan organisasi menarik orang atau pegawai seperti, dengan menjadi bagian dalam perusahaan pilihannya, untuk mempertahankan mereka dengan memberikan kesempatan yang lebih baik dan manfaat dari yang lain dan dengan memperkuat variabel psychological contract secara positif meningkatkan hubungan dukungan organisasi terhadap komitmen dan menciptakan rasa saling percaya.

$\mathrm{H}_{3}$ : Psychological Contract memoderasi dukungan organisasi terhadap komitmen organisasional

Agar mempermudah memahami gambaran serta arah penelitian mengenai pengaruh antar variabel dalam penelitian ini, maka dapat digambarkan suatu jalur pemikiran yang diterjemahkan dalam kerangka konsptual penelitian sebagai berikut.

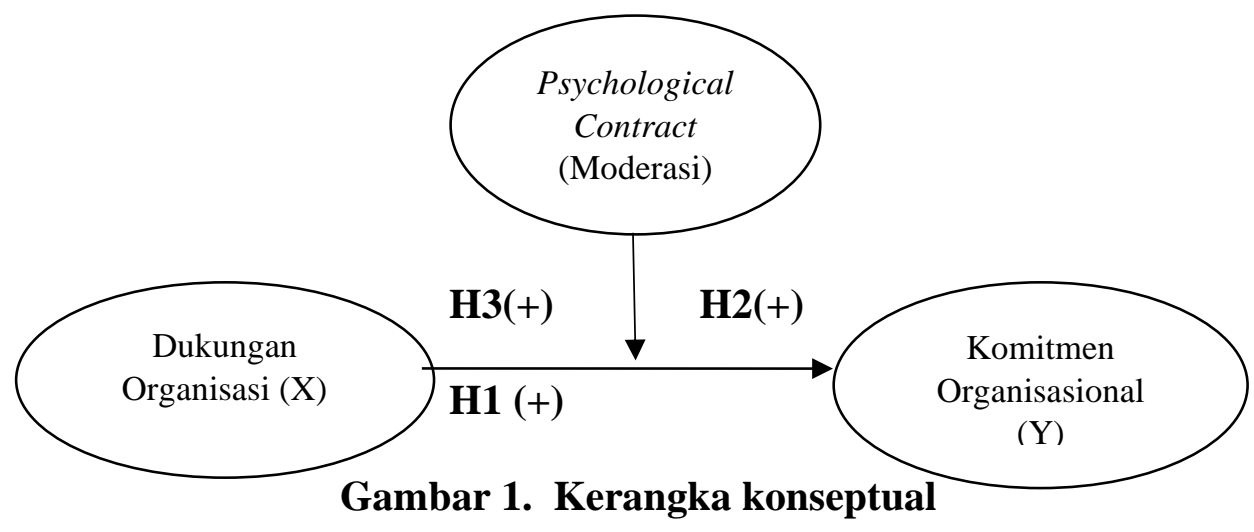

Teori Social Exchange digagas oleh Blau pada tahun 1964. Teori ini menyatakan bahwa karyawan cenderung mengembangkan hubungan berkualitas 
tinggi berdasarkan pada siapa mereka berinteraksi, bagaimana mereka berinteraksi, dan bagaimana pengalaman mereka (Blau, 2007), ketika karyawan diperlakukan dengan cara yang adil dan hormat oleh pimpinan, mereka cenderung memikirkan hubungan dengan pimpinan dalam hal pertukaran sosial dari pada pertukaran ekonomi (Brown., 2005). Mereka cenderung melakukan tindakan balasan dengan memberikan usaha ekstra ke dalam pekerjaan atau dedikasi terhadap pekerjaan yang lebih banyak dan bersedia untuk menjadi lebih baik terlibat dalam pekerjaan (Konovsky, 1994).

Komitmen organisasional merupakan faktor yang mempengaruhi diri individu pada suatu organisasi (Guest, 2016). Komitmen pada organisasi didefinisikan sebagai suatu keadaan dimana seorang karyawan memihak pada suatu organisasi tertentu dan tujuan-tujuannya, serta berniat memelihara keanggotaan dalam organisasi itu (Allen and Brady, 2008). Karyawan dianggap berkomitmen untuk sebuah organisasi jika mereka rela melanjutkan hubungan mereka dengan organisasi dan mengabdikan diri untuk mencapai tujuan organisasi (Dewi dan Rahyuda, 2015).

Dukungan organisasi dapat didefinisikan sebagai persepsi karyawan mengenai sejauh mana organisasi memberi dukungan kepada karyawan dan sejauh mana kesiapan organisasi dalam memberikan bantuan saat di butuhkan (Colakoglu ,2010). Karyawan yang memiliki dukungan organisasi merasa bahwa organisasi bersedia untuk membantu karyawannya, jika karyawannya mengalami suatu masalah di dalam organisasi, dengan demikian karyawan akan memberikan umpan balik terhadap organisasinya dengan cara meningkatkan prestasi kerja dan meningkatkan kerja sama antar karyawan (Pathak, 2012). Menurut (Wayne, 2002) juga menekankan dukungan organisasi adalah keyakinan yang dikembangkan oleh karyawan mengenai sejauh mana organisasi menghargai mereka (pegawai) dilihat dari penghargaan organisasi terhadap kontribusi mereka dan perhatian organisasi terhadap kehidupan mereka.

Shaun (Tyson., 2006) berpendapat, Psychological Contract adalah kesepakatan antara karyawan dan organisasi serta kesepakatan implisit satu sama lain yang bukan kontrak legal, diharapkan masing-masing pihak melaksanakan kewajibannya masing-masing. Menurut (Armstrong, 2003) karyawan mungkin berharap diperlakukan adil sebagai manusia, diberikan pekerjaan yang sesuai dengan kemampuan mereka dan diberikan balas jasa yang setimpal dengan kontribusi mereka, maka mereka dapat berkembang dan menunjukkan kompetensi terhadap perusahaan. Menurut (Ermawati, 2017) karyawan yang merasa diperlakukan adil dan memiliki peluang untuk tumbuh lebih lanjut, mengetahui apa yang diharapkan dari mereka dan diberikan umpan balik mengenai bagaimana pekerjaan mereka, sementara perusahaan mungkin berharap karyawan memberi kinerja terbaik mereka atas nama organisasi

(Fung, 2012) menyatakan bahwa teori pertukaran sosial merupakan pandangan karyawan ketika mereka telah diperlakukan dengan baik oleh organisasi, mereka akan cenderung untuk bersikap dan berperilaku lebih positif pada organisasi. Para karyawan lebih cenderung menganggap diri mereka berada dalam hubungan pertukaran sosial dengan para atasan mereka karena perlakuan etis yang mereka terima dan kepercayaan yang mereka rasakan, ketika karyawan 
merasa bahwa atasan mereka memiliki minat terbaik di hati dan peduli, mereka cenderung untuk membalas dengan meningkatkan kinerjanya (Guest, 2016). Psychological Contract adalah kontrak tidak tertulis yang timbul dalam diri karyawan yang muncul ketika karyawan menganggap kontribusi mereka untuk organisasi membuahkan kewajiban yang diharus dibalas oleh organisasi. (Hardiyanto,2011) menjelaskan bahwa psychological contract mewakili bagaimana orang-orang menunjukan janji dan komitmen, kedua belah pihak dalam hubungannya, maka suatu organisasi akan berjalan seperti yang diharapkan.

Karyawan bertindak berdasarkan seberapa baik organisasi memenuhi harapan karyawan dan didukung oleh dukungan organisasi, dukungan organisasi menjelaskan juga bahwa karyawan mempunyai keyakinan terhadap organisasinya, di mana kontribusi dan pertimbangan tentang kesejahtraan mereka (Eisenberger, 2002). Dukungan organisasi dipandu oleh prinsip teori sosial exchanges bahwa sebagaian besar karyawan merasa organisasi mengharagai dan mendukung mereka dalam rangka untuk mendorong komitmen organisasi. Hubungan timbal balik tersebut diperkuat dengan adanya teori pertukan sosial dimana jika seorang karyawan merasa dihargai dan diperlakukan adil terhadap organisasi maka karyawan akan meningkatkan kinerja mereka sebagai balas jasa terhadap organisasi (Blomme, 2010).

\section{METODE PENELITIAN}

Desain penelitian yang digunakan dalam penelitian ini adalah desain penelitian kausal asosiatif. Penelitian asosiatif bertujuan untuk mencari tahu pengaruh antara variabel satu dan variabel yang lain. Penelitian ini membahas mengenai pengaruh dukungan organisasi terhadap komitmen organisasional, dengan psychological contract sebagai variabel moderasi. Kuisioner digunakan sebagai instrumen utama penelitian ini dan Moderated Regression Analysis (MRA).

Populasi adalah wilayah generalisasi yang terdiri atas objek atau subjek yang mempunyai kualitas dan karakteristik tertentu yang ditetapkan oleh penelitian untuk dipelajari dan kemudian ditarik kesimpulan. Populasi dalam penelitian ini adalah seluruh karyawan pada dua perusahan tersebut yang berjumlah 100 karyawan.

Metode pengumpulan data yang digunakan dalam penelitian ini adalah: 1) Wawancara merupakan metode pengumpulan data dengan cara membuat daftar pertanyaan yang diajukan berhubungan dengan masalah yang diteliti. 2) Kuisioner Kuisioner merupakan teknik pengumpulan data yang dilakukan dengan memberikan seperangkat pernyataan atau pertanyaan terrulis kepada responden untuk dijawabnya, dimana peneliti tidak langsung bertanya jawab dengan responden. Pertanyaan atau pernyataan yang digunakan adalah metode Likert Summated Ratings (LSR), dengan alternatif pilihan 1 sampai dengan 5 jawaban pertanyaan.

(Sugiyono, 2017) menyatakan analisis statistik deskriptif adalah analisis statistik yang berfungsi untuk menganalisis data dengan cara mendeskripsikan maupun menggambarkan data penelitian yang dikumpulkan tanpa membuat kesimpulan. Namun, peneliti dapat menggunakan teknik analisis inferensial untuk bisa membuat kesimpulan yang berlaku untuk populasi penelitian. 
Fifi Prananda, Pengaruh Dukungan Organisasi...

Teknik analisis data yang digunakan dalam penelitian ini adalah Moderated Regression Analysis (MRA). Bentuk regresi ini dirancang untuk menentukan hubungan antar dua variabel yang dipengaruhi oleh variabel ketiga (variabel moderasi). Analsis MRA dalam persamaan regresinya mengandung unsur interaksi (perkalian dua atau lebih variabel independen). Adapun rumus persamaan Moderated Regression Analysis (MRA) yang digunakan adalah sebagai berikut:

$\mathrm{Y}=\alpha+\beta_{1} \mathrm{Xi}+\beta 2 \mathrm{Z}+\beta 3(\mathrm{X} . \mathrm{Z})+\mathrm{e}$.

$\mathrm{L}=\alpha+\beta 1(\mathrm{~K})+\beta 2(\mathrm{G})+\beta 3(\mathrm{~K} . \mathrm{G})+\mathrm{e}$.

Keterangan:

Y : Komitmen organisasional

$\alpha \quad$ : Konstanta

$\beta_{1}-\beta 3$ : Koefisien regresi

$\mathrm{X} \quad$ : Dukungan organisasional

Z : Psychological contract

XZ : Interaksi antara Dukungan Organisasi dengan Psychological contract

$\varepsilon \quad$ : Kesalahan atau standard eror

HASIL DAN PEMBAHASAN

Tabel 2.

Hasil Responden Karakteristik Responden

\begin{tabular}{ccccc}
\hline No & $\begin{array}{c}\text { Variabel } \\
\text { karakteristik }\end{array}$ & Klarifikasi & Jumlah & Persentase \\
& & (Orang) & \% \\
\hline 1 & Jenis Kelamin & Laki-laki & 70 & 70 \\
& & Perempuan & 30 & 30 \\
2 & Jumlah & $\mathbf{1 0 0}$ & $\mathbf{1 0 0}$ \\
& Usia & $18-27$ & 46 & 46 \\
& & $28-37$ & 39 & 39 \\
& & $38-47$ & 15 & 15 \\
3 & Jumlah & $\mathbf{1 0 0}$ & $\mathbf{1 0 0}$ \\
& \multirow{4}{*}{ Masa Kerja } & 1-5 Tahun & 45 & 45 \\
& & 6-10 Tahun & 35 & 35 \\
& & $11-15$ Tahun & 20 & 20 \\
4 & Jumlah & $\mathbf{1 0 0}$ & $\mathbf{1 0 0}$ \\
& Pendidikan & SMP & 29 & 29 \\
& & SMA & 49 & 49 \\
& & D1 & 15 & 15 \\
& & S1 & 7 & 7 \\
& & Jumlah & $\mathbf{1 0 0}$ & $\mathbf{1 0 0}$ \\
\hline
\end{tabular}

Sumber : Data diolah, 2019

Tabel 2. menyatakan karakteristik responden sebagai berikut. Karakteristik Berdasarkan jenis kelamin Tabel 2. menunjukan bahwa karyawan dengan jenis kelamin laki-laki berjumlah 70 orang atau sebesar 70 persen. Sedangkan karyawan dengan jenis kelamin perempuan berjumlah 30 orang atau sebesar 30 persen. Dari 
data tersebut menunjukan jumlah karyawan laki-laki lebih banyak karena di dalam perusahan water sport lebih banyak berkerja di lapangan dimana tenaga laki-laki lebih dibutuhkan di bandingan perempuan. Karakteristik Berdasarkan Usia Tabel 2. menunjukan bahwa karyawan dengan berdasarkan usia sebagai besar berumur 18 tahun ke atas yakni sebanyak 46 orang atau berkisar 46 persen. Artinya perusahan banyak membutuhkan karyawan yang masih muda untuk menjalankan perusahaannya. Berdasarkan Masa Kerja Tabel 2. menunjukan sebagian besar responden dalam penelitian ini memiliki masa kerja antara 1 sampai 5 tahun, yaitu sebanyak 45 orang atau 45 persen, dan masa kerja 6 sampai 10 tahun berjumlah 35 orang atau 35 persen, dan masa kerja 11 sampai 15 tahun berjumblah 20 orang atau 20 persen. Hal ini menunjukan bahwa perusahaan lebih banyak menerima karyawan baru dikarenakan usia mereka lebih muda dan masih produktif. Karakteristik Berdasarkan Pendidikan Terakhir Tabel 2 menunjukan bahwa pendidikan terakhir dari karyawan dua perusahaan water sports adalah SMA/SMK yang paling banyak 49 orang atau 49 persen dan untuk pendidikan SMP yaitu 29 orang atau 29 persen, dan sisanya D1 dan S1 yakni di pentingkan dalam perusahan karena 15 dan 7 orang atau 15 persen dan 7 persen. Ini berakti tingkat pendidikan tidak terlalu dibutuhkan saat berkerja dalam perusahaan water sportInstrumen penelitian dalam penelitian ini berupa kuesioner yang disebarkan langsung kepada responden, terdiri dari pertanyaan tertutup serta pertanyaan terbuka. (Sugiyono, 2017) menyatakan bahwa pertanyaan tertutup terdiri atas beberapa pertanyaan tentang identitas responden, sedangkan pertanyaan terbuka terdiri atas sejumlah pertanyaan yang meminta pendapat responden tentang penilaiannya terhadap sejumlah indikator dan setiap variabel. Pertanyaan terbuka pada kuesioner ini diukur menggunakan skala Likert 5 poin.

Analisis statistik deskriptif digunakan untuk memperoleh gambaran mengenai karakteristik responden penelitian dari beberapa aspek, seperti: umur, jenis kelamin, pendidikan, dan masa kerja. Analisis deskriptif ini dilakukan dengan analisis distribusi frekuensi dengan menghitung frekuensi atau jumlah dan persentase dari masing-masing aspek yang diukur. . Dengan analisis deskriptif ini diperoleh gambaran persepsi responden terhadap indikator-indikator yang merefleksikan variabel penelitian. Solimun et al. (2017) menyatakan bahwa penilaian secara kuantitatif menggunakan skala interval dengan mengintegrasikan rata-rata skor menurut kategori penilaiannya adalah sebagai berikut.

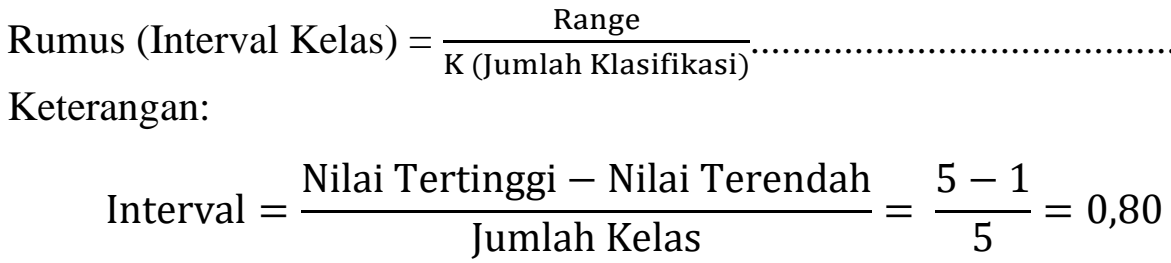

$$
\begin{aligned}
& \mathrm{K}=\text { Jumlah Klasifikasi }=>5 \\
& \text { Skor } 1-1,80 \text { : Sangat Rendah } \\
& \text { Skor } 1,80>-2,60 \quad \text { : Rendah }
\end{aligned}
$$




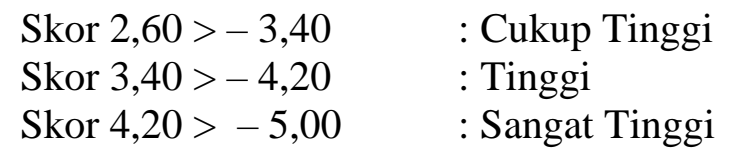

Tabel 3

Deskripsi Variabel Komitmen Organisasional

\begin{tabular}{|c|c|c|c|c|c|c|c|c|}
\hline \multirow[t]{2}{*}{ No } & \multirow[t]{2}{*}{ Pernyataan } & \multicolumn{5}{|c|}{$\begin{array}{l}\text { Proporsi Jawaban } \\
\text { Responden }(\%) \\
\end{array}$} & \multirow[t]{2}{*}{$\begin{array}{l}\text { Rata- } \\
\text { Rata }\end{array}$} & \multirow[t]{2}{*}{ Kriteria } \\
\hline & & STS & TS & $\mathbf{N}$ & $\mathbf{S}$ & SS & & \\
\hline 1 & $\begin{array}{l}\text { Saya mempunyai rasa memiliki } \\
\text { yang kuat terhadap organisasi }\end{array}$ & 0 & 11 & 7 & 45 & 37 & 4,08 & Tinggi \\
\hline 2 & $\begin{array}{l}\text { Saya bertanggung jawab atas } \\
\text { keberhasilan organisasi }\end{array}$ & 0 & 19 & 8 & 43 & 30 & 3,84 & Tinggi \\
\hline 3 & $\begin{array}{l}\text { Saya senang menghabiskan sisa } \\
\text { karir saya di perusahaan ini. }\end{array}$ & 0 & 5 & 13 & 54 & 28 & 4,05 & Tinggi \\
\hline 4 & $\begin{array}{l}\text { Saya merasa perusahaan banyak } \\
\text { berjasa bagi saya. }\end{array}$ & 0 & 4 & 14 & 52 & 30 & 4,08 & Tinggi \\
\hline 5 & $\begin{array}{l}\text { Saya berupaya optimal untuk } \\
\text { memberikan hasil pemikiran } \\
\text { untuk memajukan organisasi. }\end{array}$ & 0 & 1 & 13 & 56 & 30 & 4,15 & Tinggi \\
\hline 6 & $\begin{array}{l}\text { Akan sulit bagi saya untuk } \\
\text { meninggalkan perusahaan }\end{array}$ & 0 & 3 & 13 & 64 & 20 & 4,01 & Tinggi \\
\hline \multicolumn{7}{|c|}{ Rata-rata Komitmen Organisasional } & 4,35 & $\begin{array}{l}\text { Sangat } \\
\text { Tinggi }\end{array}$ \\
\hline
\end{tabular}

Sumber : Data Diolah, 2019

Komitmen organisasional merupakan varibel terikat yang digunakan dalam penelitian ini yang diukur dengan menggunakan 6 item pernyataan. Berdasarkan Tabel 3. dapat menunjukkan bahwa 6 item pernyataan yang terkait dengan komitmen organisasional yaitu total nilai rata-rata sebesar 4,35 dan masuk dalam kriteria tinggi. Dalam hal ini berakti dapat di lihat dengan Nilai rata-rata tertinggi jawaban responden ditunjukan pada dua pernyataan "Saya senang menghabiskan karir saya di perusahaan ini " dengan nilai rata-rata sebesar 4,08 dan "Saya berupaya optimal untuk memberikan hasil pemikiran untuk memajukan organisasi" dengan nilai rata-rata sebesar 4,15 , terdapat dua pernyataan yang masuk dalam kriteria sangat tinggi, hal ini menunjukan bahwa karyawan memiliki komitmen tinggi dengan bersedia memberikan hasil optimal untuk memajukan perusahaan dan inggin menghabiskan karirnya di dalam perusahaan. Serta juga ada pernyataan "Saya bertanggung jawab atas keberhasilan perusahaan " dengan nilai rata-rata 3,84 masuk dalam katagori tinggi ini artinya, karyawan merasa bahwa keberhsilan perusahaan juga keberhasilan mereka. Selanjutnya ada pernyataan bahwa "Saya merasa perusahaan banyak berjasa bagi saya " dengan skors 4,08 dengan katagori tinggi, ini artinya karyawan merasa bahwa perusahan banyak berjasa bagi mereka misalnya dengan kenaikan karir merekaa ataupun bonus yang mereka dapatkan. 
Tabel 4.

Deskripsi Variabel Dukungan Organisasi

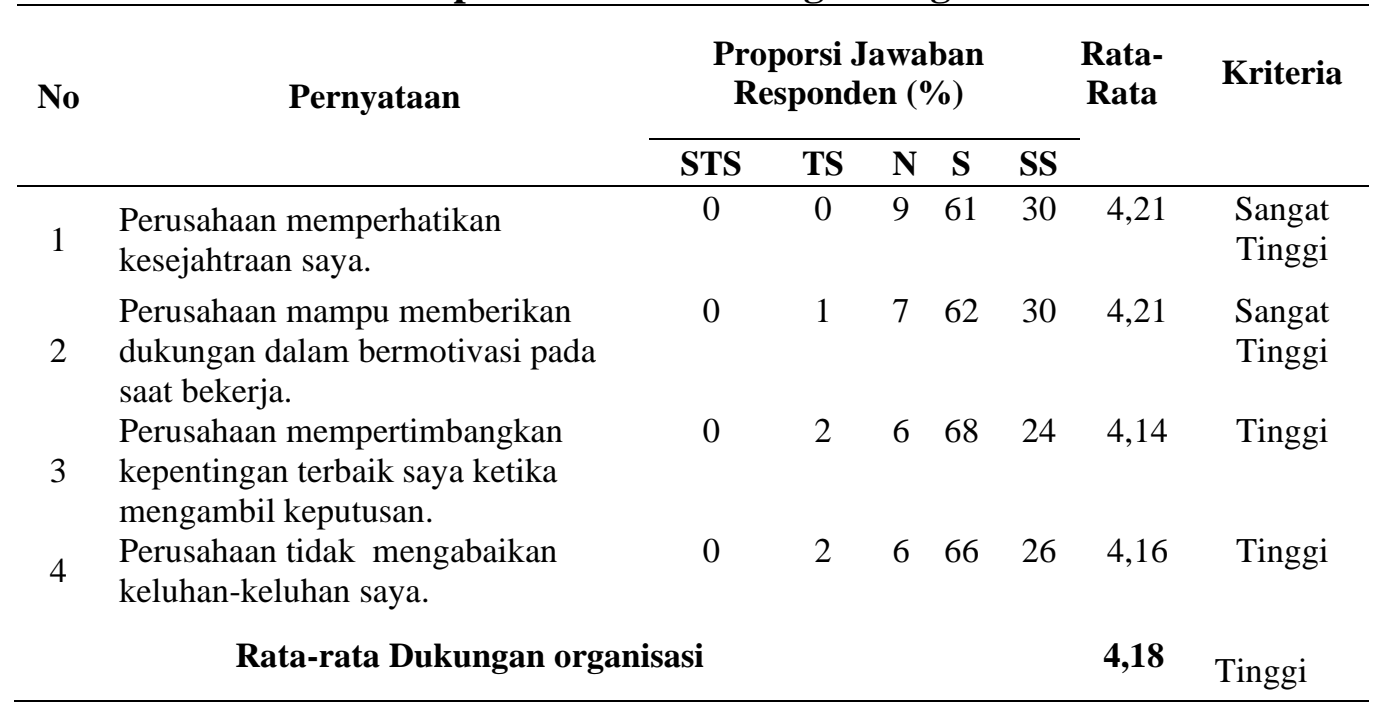

Sumber : Data diolah, 2019

Dukungan organisasi merupakan variabel bebas yang diukur dengan menggunakan 4 item pernyataan berdasarkan Tabel 4. dapat dilihat nilai rata-rata 4,18 dan masuk dalam kriteria sangat tinggi dengan diukur melalui indikator terkait dukungan organisasi. Nilai rata-rata tertinggi jawaban responden ditunjukan pada dua pernyataan yaitu "Perusahaan memperhatikan kesejahtraan saya" dan "Perusahaan mampu memberikan dukungan dalam bermotivasi pada saat bekerja" yaitu dengan nilai rata-rata 4,21 dengan kriteria sangat tinggi. Artinya karyawan merasa bahwa perusahaan memperhatikan kesejahtraan mereka dan perusahaan juga mampu memberikan motivasi saat karyawan berkerja demi keberhasilan perusahaan, dan juga ada pertanyaatan "Perusahaan mempertimbangkan kepentingan saya saat mengambil keputusan" dengan nilai rata-rata 4,14 dengan katogori tinggi, artinya karyawan merasa di butuhkan didalam perusahaan dan perusahaan mengambil keputusan sudang mempertimbangkan kepentingan seorang karyawanya. Pernyataan dengan "Perusahaan tidak mengabaikan keluhan-keluhan saya" dengan nilai rata-rata 4,16 dengan kategori tinggi, ini artinya perusahaan tidak mengabaikan keluhan yang dirasakan oleh karyawan, seperti mungkin kenaikan gaji ataupun bonus yang kurang bagi karyawan, perusahaan juga mempertimbangkan keluhan yang dirasakan oleh karyawan dengan memngambil pertimbangan yang tepat, serta melihat penjualan atau pendapatan yang diberikan dapatkan oleh karyawan, jadi perusahaan mau mempertimbangkan keluhan serta mencarikan solusi terbaik untuk perusahaan agar bisa mencapai tujuan dan visi misi awal perusahan. Dapat dilihat di 4 item pernyataan bahwa terdapat variabel yang sangat tinggi nilai rata-ratanya yaitu 4,21 dengan ini maka dapat dilihat bahwa perusahaan memberikan kesejahtraan terhadap karywan dengan memberikan gaji, bous tiap hari jika watersport banyak ada pengujung maka karyawan akan ruti diberikan bonus berapa uang, maka dari itu karyawan harus berupaya keras agar perusahaan dapat mencapai tujuan bersama mereka yaitu mencapai visi misi dengan memberikan kinerja yang baik. 
Tabel 5.

Deskripsi Variabel Psychological Contract

\begin{tabular}{|c|c|c|c|c|c|c|c|c|}
\hline \multirow{3}{*}{ No } & \multirow{3}{*}{ Pernyataan } & \multicolumn{6}{|c|}{ Proporsi Jawaban } & \multirow{3}{*}{ Kriteria } \\
\hline & & \multicolumn{5}{|c|}{ Responden (\%) } & \multirow{2}{*}{$\begin{array}{l}\text { Rata- } \\
\text { Rata }\end{array}$} & \\
\hline & & STS & & $\mathbf{S}$ & $\mathbf{S}$ & SS & & \\
\hline 1 & $\begin{array}{l}\text { Saya merasa adanya hubungan } \\
\text { timbal balik secara emosional dengal } \\
\text { perusahaan }\end{array}$ & 0 & 1 & 10 & 68 & 21 & 4,09 & Tinggi \\
\hline 2 & $\begin{array}{l}\text { Saya merasa nyaman bekerja di } \\
\text { perusahaan }\end{array}$ & 0 & 0 & 11 & 59 & 30 & 4,19 & Tinggi \\
\hline \multicolumn{7}{|c|}{ Rata-rata Kontrak Relasional } & 4,14 & Tinggi \\
\hline 1 & $\begin{array}{l}\text { Saya tidak memiliki kewajiban untul } \\
\text { tetap berkerja di perusahaan ini }\end{array}$ & 0 & 0 & 13 & 63 & 24 & 4,11 & Tinggi \\
\hline 2 & $\begin{array}{l}\text { Remunerasi yang saya terima } \\
\text { sesuai dengan beban kerja yang } \\
\text { diberikan. }\end{array}$ & 0 & 1 & 9 & 63 & 27 & 4,16 & Tinggi \\
\hline \multicolumn{7}{|c|}{ Rata-Rata Balanced Contract } & 4.135 & $\begin{array}{l}\text { Sangat } \\
\text { Tinggi }\end{array}$ \\
\hline 1 & $\begin{array}{l}\text { Perusahan memberikan } \\
\text { kesempatan pelatihan untuk } \\
\text { perkembangan diri saya }\end{array}$ & 0 & 3 & 11 & 61 & 25 & 4,08 & Tinggi \\
\hline 2 & $\begin{array}{l}\text { Perusahan selalu memberikan } \\
\text { bimbingan untuk } \\
\text { mengembangkan karir saya }\end{array}$ & 0 & 1 & 13 & 61 & 25 & 4,10 & Tinggi \\
\hline \multicolumn{7}{|c|}{ Rata-rata Kontrak R } & 4,09 & Tinggi \\
\hline \multicolumn{7}{|c|}{ Rata-Rata Psychological contract } & 4,122 & $\begin{array}{l}\text { Sangat } \\
\text { Tinggi }\end{array}$ \\
\hline
\end{tabular}

Sumber : Data Diolah, 2019

Psychological contract yang merupakan variabel moderasi yang diukur menngunakan 6 item pernyataan dapat dilihat di Tabel 5 bahwa nilai rata-rata 4.122 yang tergolong kategori sangat tinggi dengan diukur melalui indikator terkait dengan psychological contract. Nilai rata-rata tertinggi jawaban responden ditunjukan pada pernyataan "saya merasa nyaman berada didalam perusahaan" dengan nilai 4.19 yaitu kategori sangat tinggi, yang artinya karyawan merasa nyaman berkerja di perusahaan, adapun juga pernyataan " Remunerasi yang saya terima sesuai dengan beban kerja yang diberikan" dengan nilai rata-rata 4,16 yaitu dengan kategori sangan tinggi, dalam hal ini berakti perusahaan memberikan remunerasi sesuai dengan pekerjaan yang telah diselesaikan oleh karyawan dengan memberikan secara adil.

Instrumen penelitian dalam penelitian ini berupa kuesioner yang disebarkan langsung kepada responden, terdiri dari pertanyaan tertutup serta pertanyaan terbuka dengan menggunakan pengukuran skala likert 5 poin. Instrumen penelitian dikatakan valid apabila instrumen yang digunakan dapat mengukur apa yang seharusnya diukur. Suatu instrumen dikatakan valid jika nilai koefisien korelasi $r-$ hitung lebih besar dari 0,30 dengan tingkat kesalahan kurang dari $\alpha=0,05$. Hasil uji validitas ditunjukkan pada Tabel 6 . 
Tabel 6.

Rekapitulasi Hasil Uji Validitas

\begin{tabular}{cccc}
\hline Variabel & Item & $\begin{array}{c}\text { Corrected Item- } \\
\text { Total } \\
\text { Correlation }\end{array}$ & Ket. \\
\hline Komitmen Organisasional (Y) & Y1.1 & 0,853 & Valid \\
& Y2.2 & 0,683 & Valid \\
& Y3.3 & 0,859 & Valid \\
& Y4.4 & 0,720 & Valid \\
& Y5.5 & 0,723 & Valid \\
& Y6.6 & 0,543 & Valid \\
Dukungan Organisasi (X) & X1.1 & 0,886 & Valid \\
& X2.2 & 0,884 & Valid \\
& X3.3 & 0,868 & Valid \\
Pscyhological Contract (M) & X4.4 & 0,713 & Valid \\
& M1.1 & 0,802 & Valid \\
& M1.2 & 0,899 & Valid \\
& M2.1 & 0,888 & Valid \\
& M2.2 & 0,861 & Valid \\
& M3.1 & 0,874 & Valid \\
& M3.1 & 0,930 & Valid \\
\hline
\end{tabular}

Sumber : Data Diolah,2019

Hasil uji dapat dilihat dalam Tabel 6. yaitu validitas pada tabel diatas menunjukan bahwa seluruh variabel memiliki nilai koefisien korelasi dengan skor total seluruh item pernyataan lebi besar 0,30 . Hal ini menunjukan bahwa butir-butir pernyataan sisanya dalam instrument penelitian tersebut valid.

Pengujian reabilitas menunjukan sejauh mana suatu alat pengukuran dapat dipercaya atau dapat diandalkan. Suatu instrument dikatakan reliable, jika instrument tersebut memiliki nilai Alpha Cronbach lebih dari 0,60.

Tabel 7.

Rekapitulasi Hasil Uji Reabilitas

\begin{tabular}{llcl}
\hline No & \multicolumn{1}{c}{ Variabel } & Cronbach's Alpha & Ket \\
\hline 1 & Komitmen Organisasional (Y) & 0,817 & Reliabel \\
2 & Dukungan Organisasi (X) & 0,856 & Reliabel \\
3 & Psychological Contract (M) & 0,609 & Reliabel \\
\hline
\end{tabular}

Sumber : Data Diolah,2019

Uji reliabilitas menunjukkan sejauh mana suatu pengukuran dapat menghasilkan data yang sama (konsisten) bila dilakukan pengukuran beberapa kali terhadap obyek yang sama, Dalam penelitian ini, untuk menguji reliabilitas data digunakan bantuan komputer dengan perangkat lunak SPSS for Windows 20.0. Nilai suatu instrumen dikatakan reliabel bila nilai Alpha Cronbach $\geq 0,6$. Hasil uji reliabilitas pada Tabel 7. menunjukkan bahwa variabel penelitian memiliki koefisien Cronbach's Alpha lebih dari 0,60. Jadi dapat dinyatakan bahwa seluruh variabel telah memenuhi syarat reliabilitas atau kehandalan sehingga dapat digunakan untuk dianalisis lebih lanjut 
Tabel 8.

Hasil Uji Interaksi (Moderated Regression Analysis)

\begin{tabular}{|c|c|c|c|c|}
\hline \multirow[b]{2}{*}{ Model } & \multicolumn{2}{|c|}{ Koefisien Regresi } & \multirow[b]{2}{*}{$\mathbf{T}$} & \multirow[b]{2}{*}{ Sig. } \\
\hline & B & Std. Error & & \\
\hline (Constant) & 3,901 & 0,079 & 49,558 & 000 \\
\hline Dukungan Organisasi (X) & 0,130 & 0,055 & 2,364 & 020 \\
\hline Psychological Contract (M) & 0,272 & 0,055 & 4,940 & 000 \\
\hline Interaksi $\left(\mathrm{X}^{*} \mathrm{M}\right)$ & 0,166 & 0,078 & 2,141 & 035 \\
\hline \multicolumn{5}{|c|}{ Dependent Variabel : Komitmen Organisasional } \\
\hline F Hitung & & & & \\
\hline$: 0,000$ & & & & \\
\hline$: 0,340$ & & & & \\
\hline
\end{tabular}

Sumber : Data Diolah, 2019

Persamaan regresi moderasi pada Tabel 8. dapat dijelaskan untuk setiap variabel hal-hal sebagai berikut : $\mathrm{Y}=0.130 \mathrm{X}+0.272 \mathrm{M}\left|+0.166 \mathrm{X}^{*} \mathrm{M}\right|$. Nilai koefien $\beta_{1}$, nilai koefisien $\beta_{1}$ yang diperoleh sebesar 0,130 menunjukan bahwa interaksi antara variabel dukungan organisasi dan psychological contract bersifat positif. Artinya interaksi dukungan organisasi yang baik akan meningkatkan komitmen karyawan sehingga akan tetap berada didalam organisasi dan akan menguntungkan perusahaan.Nilai koefisien $\beta_{2}$, Nilai koefisien $\beta_{2}$ yang diperoleh sebesar 0,272 menunjukan bahwa interaksi antara variabel psychological contract dan komitmen organisasional bersifat positif. Artinya interaksi psychological contract yang baik tentunya akan menimbulkan komitmen karyawan.Nilai koefisien $\beta_{3}$, nilai koefisien $\beta_{3}$ yang diperoleh sebesar 0,166 menunjukan bahwa interaksi anatara variabel dukungan organisasi terhadap komitmen organisasi dimoderasi atau diperkuat oleh psychological contract secara positif. Artinya interaksi psychological contract memperkuat pengaruh dukungan organisasi dalam meningkatkan komitmen karyawan.

Tabel 9.

Hasil Uji Kesesuaian Model (Uji F)

\begin{tabular}{lccccc}
\hline \multicolumn{1}{c}{ Model } & $\begin{array}{c}\text { Sum of } \\
\text { squares }\end{array}$ & Df & $\begin{array}{c}\text { Mean } \\
\text { square }\end{array}$ & F & Sig. \\
\hline Regression & 11,335 & 3 & 3,778 & 16,460 & $.000^{\text {a }}$ \\
Residual & 22,037 & 96 & 0.230 & & \\
Total & 33,372 & 99 & & & \\
\hline
\end{tabular}

Sumber: Data Diolah, 2019

Uji Signifikan simultan (Uji statistic F) digunakan untuk mengetahui pengaruh variabel bebas secara bersama-sama (simultan) terhadap variabel terikat. Langkah - langkah yang ditempuh dalam pengujian adalah menyusun hipotesis nol $\left(\mathrm{H}_{0}\right)$ dan hipotesis alternative $\left(\mathrm{H}_{1}\right)$, dapat dilihat hasil uji statistic $\mathrm{F}$ pada Tabel 9. menunjukan hasil nilai signifikansi sebesar 0,000 yang lebih kecil dari tingkat $\alpha=$ 0,05 . Hal ini berakti dukungan organisasi dan komitmen organisasional secara bersama berpengaruh signifikan dalam psychological contract. Hal ini mengindikasikan bahwa model yang digunakan dalam penelitian ini layak dipergunakan. 
Uji t digunakan untuk menguji pengaruh dari variabel dukungan organisasi, terhadap variabel komitmen organisasional dengan psychological contract sebagai variabel moderasi. Kriteria penerimaan dan penolakannya sebagai berikut:

Jika sig.t $>\alpha 0,05$ maka $\mathrm{H}_{0}$ diterima atau $\mathrm{H}_{\mathrm{a}}$ ditolak, Jika sig.t $\leq \alpha 0,05$ maka $\mathrm{H}_{\mathrm{a}}$ diterima dan $\mathrm{H}_{0}$ ditolak Adapun hasil uji t sebagai berikut : Pengaruh dukungan organisasi terhadap komitmen organisasional. Hasil perhitungan uji t dapat dilihat pada Tabel 8. Daari tabel tersebut diketahui bahwa nilai koefisien regresi $\mathrm{X}$ adalah sebesar 0,130 dengan tingkat signifikan sebesar 0,020 lebih kecil dibandingkan dengan taraf nyata $\alpha=0,05$. Hal ini menunjukan bahwa dukungan organisasi berpengaruh positif dan signifikan terhadap komitmen organisasional di dua perusahan. Semakin baik dukungan organisasi yang diberikan oleh perusahan semakin tinggi karyawan akan tetap tinggal didalam perusahan. Hipotesis yang menyatakan bahwa dukungan organisasi berpengaruh positif signifikan terhadap komitmen organisasional. Pengaruh psychological contract terhadap komitmen organisasional. Hasil perhitungan uji t dapat dilihat pada Tabel 8. Dari tabel tersebut diketahui bahwa nilai koefisien regresi $\mathrm{M}$ adalah 0,272 dengan tingkat signifikan 0,000 lebih kecil dibandingkan dengan taraf nyata $\alpha=0,5$. Hal ini menunjukan bahwa psychological contract berpengaruh positif dan signifikan terhadap komitmen organisasional di dua perusahaan. Semakin kuat psychological contract yang dirasakan oleh karyawan maka akan semakin tinggi komitmen karyawan. Hipotesis yang menyatakan bahwa psychological contract berpengaruh positif dan signifikan terhadap komitmen organisasional. psychological contract moderasi Pengaruh dukungan organisasi terhadap komitmen organisasiona Hasil berhitungan uji t dapat dilihat pada Tabel 8. Dari tabel tersebut diketahui bahwa nilai koefisien regresi $\left|\mathrm{X}^{*} \mathrm{M}\right|$ adalah sebesar 0,166 dengan tingkat signifikan 0,035 lebih kecil dibandingkan dengan taraf nyata $\alpha=0,05$. Hal ini menunjukan bahwa psychological contract yang dimiliki oleh karyawan secara langsung memperkuat dan berpengaruh positif dukungan organisasi terhadap komitmen organisasional di dua perusahaan water sport, artinya semakin baik psychological contract yang dimiliki oleh karyawan maka dukungan organisasi yang diterima karyawan akan semakin baik sehingga mampu membuat karyawan berada tetap didalam sebuah organisasi.

Pengujian koefisien determinasi $\left(\mathrm{R}^{2}\right)$ dilakukan untuk mengetahui seberapa besar variasi variabel dependent akan mampu dijelaskan oleh variabel independenya, sedangkan sisanya dijelaskan oleh sebab-sebab variabel lain di luar model.

Tabel 10.

Hasil Analisis Koefisien Determinasi $\left(\mathbf{R}^{2}\right)$

\begin{tabular}{cccc}
\hline $\mathbf{R}$ & R Square & Adjusted R Square & Std. Error of the Estimate \\
\hline $0,583^{\text {a }}$ & 0,340 & 0,319 & 0,47911 \\
\hline Sumber: Data Diolah, 2019 & &
\end{tabular}

Berdasarkan Tabel 10. menunjukan bahwa nilai $\mathrm{R}$ squer model 0,340 sehingga dapat dihitung persentase kontribusi dukungan organisasi, komitmen organisasional dan psychological contract dapat dijelaskan bahwa $34,0 \%$ persen dan sisanya yaitu $66,0 \%$ persen dipengaruhi oleh variabel lain diluar penelitian. 
Hasil uji parsial menunjukan bahwa psychological contract memperkuat pengaruh positif dan signifikan dukungan organisasi dalam meningkatkan komitmen organisasional di perusahaan wisata bahari water sport. Teori Social Exchange menyatakan bahwa karyawan cenderung mengembangkan hubungan berkualitas tinggi berdasarkan pada siapa mereka berinteraksi, dan mereka akan cendrung membalas jasa apa yang diberikan oleh organisasi untuk mereka.

Hasil penelitian ini sama dengan Penelitian yang dilakukan oleh (Maria, 2016), (Jabeen, 2015), (Kiazad, 2014), (Van den, 2015), (Low, 2016) bahwa psychological contract secara memodesi dukungan organisasi terhadap komitmen organisasional, yang menjelaskan organisasi menarik orang atau pegawai seperti, dengan menjadi bagian dalam perusahaan pilihannya, untuk mempertahankan mereka dengan memberikan kesempatan yang lebih baik dan manfaat dari yang lain dan dengan memperkuat variabel psychological contract secara positif meningkatkan hubungan dukungan organisasi terhadap komitmen dan menciptakan rasa saling percaya.

Hasil penelitian ini memberikan sebuah implikasi teoritis Penelitian ini akan memberikan implikasi terhadap tindakan manajemen tentang pentingnya dilakukan suatu perubahan khusus untuk meningkatkan komitmen karyawan. penenlitian ini akan menentukan bagaimana seorang karyawan memiliki hubungan kuat terhadap perusahaan. Penelitian ini akan mampu menciptakan kondisi yang efektif dan efisien, tidak hanya pada pengembangan SDM karyawan itu sendiri namun akan terciptanya loyalitas karyawan terhadap perusahaan.

Patut disadari bahwa terdapat beberapa keterbatasan dalam penelitian ini yaitu, sebagai berikut: 1) Penelitian ini hanya menggunakan teknik analisi moderasi (MRA). Sedangkan dapat dikembangkan lagi dengan teknik analisis lainnya seperti konfirmatori dan SEM analisis dan path analisis. 2) Penelitian hanya dilakukan dalam titik waktu tertentu (cross section), sedangkan lingkungan dan kebutuhan bersifat dinamis, sehingga penelitian penting untuk dilakukan kembali di masa mendatang dengan menambah variabel lain yang tidak dimasukkan di dalam model yang juga dapat memengaruhi komitmen organisasional karyawan. 3) Penelitian ini masih mengalami kesulitan dalam memberikan pemahaman kepada responden tentang fungsi penelitian ini, dikarenakan responden kebanyakan masih memikirkan money oriented.

\section{SIMPULAN}

Berdasarkan hasil yang telah diuraikan, maka didapatkan simpulan sebagai berikut : Dukungan organisasi berpengaruh positif dan signifikan terhadap komitmen karyawan, artinya dukungan organisasi yang di berikan oleh organisasi mampu meningkatkan komitmen karyawan. Psychological contract berpengaruh positif dan signifikan terhadap komitmen organisasional, artinya psychological contract yang dirasakan oleh karyawan mampu meningkatkan komitmen karyawan. Psychological contract memperkuat pengaruh dukungan organisasi terhadap komitmen organisasional, artinya psychological contract yang positif akan mendukung terlaksananya dukungan organisasi untuk karyawan sehingga akan menimbulkan komitmen organisasional. 
Berdasarkan simpulan diatas, maka saran yang dapat diberikan sesuai dengan hasil rata-rata terkecil deskriptif penelitian adalah sebagai berikut : 1) Pihak manajemen dalam menghadapi karyawan haruslah adil dengan adanya indikasi yang ditujukan oleh karyawan, yaitu berupa tidak naik jabatan walaupun sudah lama berkerja di perusahaan. 2) Perusahaan menanamkan sikap komitmen pada karyawan dengan membangun rasa kebersamaan, rasa memiliki, sikap saling menghargai, menciptakan suasana kerja yang kondisif dan menyenangkan karyawan, dan yang paling terpenting karyawan haruslah merasa dibutuhkan oleh perusahaan agar karyawan memiliki rasa memiliki terhadap perusahaan. 3) Pemimpin harus mampu memahami perbedaan individual setiap karyawannya, dengan lebih memperhatikan setiap idea atau masukan yang diberikan karyawan. Pemimpin dan karyawan harus membina komunikasi yang baik, pemimpin dan karyawan harus merasa adanya hubungan timbal balik agar perusahaan dan karyawan dapat mencapai tujuan

\section{REFERENSI}

Agustiningrum Sherly. (2016). Pengaruh Dukungan Organisasi Terhadap Kinerja Karyawan yang Dimediasi oleh OCB (Organizational Citizenship Behavior) Studi Pada PT. Angkasa Pura 1 kantor Cabang Surabaya. Jurnal Ilmu Manajement., 4(2), 67-69.

Ahmed, I., and Nawaz, M. M. (2015). Antecedents and outcomes of perceived organizational support: a literature survey approach. Journal of Management Development., 34(7), 867-880.

Allen, M. and Brady, R. (2008). Total Quality Management, Organizational Commitment, Perceived Organizational Support, and Intraorganizational Communication, Management Communication Quarterly,. Journal Management Communications Quarterly, 10(3), 316-341.

Anggraeni, A.I., Dwiatmadja, C,. dan Yuniawan, A. (2017). The role of psychological contract on employee commitment and organisational citizenship behaviour: A study of Indonesian young entrepreneurs in management action. SA Journal of Industrial Psychology., 2(6), 2071-0763.

Anoraga.(2005). Psikologi Kerja(Edisi Dua). Rineka Cipta.

Armstrong, M. (2003). How to be AnEven Better Manager. Binarupa Aksara.

Blau, P. M. (2007). Exchange and Power in SocialLife. Wiley.

Blomme, R.J., Rheedeb A., dan Trompb, D. M. (2010). The use of the psychological contract to explain turnover intentions in the hospitality industry: aresearch study on the impact of gender on the turnover intentions of highly educated employees. The International Journal of Human Resource Management, 21(1), 144-162. 
Brown.(2005). Social Exchange Theory. Selempang.

Colakoglu Ulker, Osman Culha, H. A. (2010). TheEffects of Perceived Organisational Support on Employees' Affective Outcomes: Evidence From the Hotel Industyr. Journal Tourismand Hospitality Management., 16(2), 125-150.

Coyle-Saphiro, Jacqueline A-M. \& Kessler, I. (2000). Consequences of psychological contract for the employment relationship: A large scale survey,. Journal of Management Studies, 37(7), 903-930.

Cristiana, Merry., dan Sunjoyo. (2016). Pengaruh Kepuasan Kerja Terhadap Komitmen Organisasional yang Dimediasi oleh Identifikasi Organisasional. Jurnal Manajemen Fakultas Ekonomi Universitas Kristen Maranatha. 6 (8), $60-79$

Cropanzano, R., Bowen, D.E., \& Gilliland, S. W. (2007). The Management Of Organizational Justice. Academy of Management Perspectives, 21(4), 34-48.

Dewi, M.P, dan Rahyuda, A. G. (2015). Peran Pemediasi Komitmen Organisasi Pada Pengaruh Perceived Organizational Support Terhadap Intention To Leave. EJurnal Manajement Unud,4(10), 2928-2954.

Diana Sulianti. (2009). Pengaruh Komitmen Organisasional dan Kepuasan Kerja Terhadap Kinerja Karyawan. Jurnal Manajemen \& Kewirausahaan, 11(1), $31-37$

Eisenberger, R, Rhoades, L. (2002). Percevied Supervisor Support: Contributions to Percevied organizational support and employee retention. Journal of Applied Psychology., 87(3), 565-573.

Ermawati, E. (2017). Pengaruh Kontrak Psikologis Dan Komitmen Organisasi terhadap Kinerja Karyawan di Klinik Husada Mulia Kabupaten Lumajang. Jurnal IlmiahAkuntansi Keuangan Dan Pajak, 1(7), 78-82.

Ferdinand Augusty. (2013). Metode Penelitian Manajemen. Semarang. Badan Penerbit Universitas Diponegoro.

Fung, N.S., A. A. and Z. O. (2012). Work-Family Enrichment: It's Mediating Role in the Relationships between Dispositional Factors and Job Satisfaction. International Journal of Academic Research in Business and Social Sciences, 2(11),73-88.

Ghozali, Imam. (2011). Aplikasi Analisis Multivariate dengan Program SPSS 19. (edisi kelima). Semarang: Universitas Diponegoro.

Griffin, M. (2013). Perilaku Organisasi (Manajemen Sumber Daya Manusia dan Organisasi). SalembaEmpat. 
Guest, D.E. (2016). Trust and the role of the psychological contract in contemporary employment relations. In P. Elgoibar, L. Munduate, \& M. Euwema (Eds). Building trust and Constructive Conflict Management in Organizations

Hardiyanto R. (2011). Pengaruh Kontrak Psikologis dan Keadilan Distributif Terhadap Employee Engagement yang Berdampak pada Keefektifan Kerja Karyawan Hotel Jentra Dagen, Laxton, dan Covinton Yogyakarta. Jurnal Management 5(2), 48-52

Herriot, P., dan Pemberton, C. (1997). Facilitating new deals. Human Resource Management Journal, 7(1), 45-56.

Jabeen f., Beherym. \& Elanain H.A. (2015). Examining the relationship between the psychological contract and organizational commitment: The mediating effect of transactional leadership in the UAE context. International Journal of OrganizationalAnalysis, 23(1), 102-122.

Karagonlar, G., Eisenberger, R., \& Aselage, J. (2016). Reciprocation wary employees discount psychological contract fulfillment. Journal of Organizational Behavior, 37(1), 23-40.

Kiazad, K., Kraimer, M., \& Seibert, S. (2014). A job embeddedness perspective on responses to psychological contract fulfillment. In Academy of management proceedingr, 1(1) 23-62.

Konovsky, Pugh. (1994). Citizenship Behavior and Social Exchange. Academy Management Journal, 37(3): 656-696.

Liao-Troth, A. (2005). The Effects of Functional Motives and Personality Factors on the Psychological Contracts of Volunteers. Nonprofit and Voluntary Sector Quarterly, 34(4), 510-530.

Low, C.H., Bordia, P., \& Bordia, S. (2016). What do employees want and why? An exploration of employees' preferred psychological contract elements across career stages. Human Relations, 69(7), 1457-1481.

Malayu S. P. Hasibuan. (2016). Manajemen : Dasar, Pengertian, dan Masalah, Edisi Revisi, Bumi Aksara, Jakarta.

Maria, J., Chambel, Laura., Lorente, Vania., Carvlho, and Isabel Maria Martinez. (2016). Psychological contract profiles among permanent and temporary agency workers. Journal of Managerial Psychology, 31(1), 79-94

Millward, Hopkins (1998). Psychological contracts, organizational and job commitment. Journal OfApplied Social Psychological. 28(16), 1530-1556 
Mullen, T. R. Kroustalis, C., Meadem, A.W., and Surface, E. A. (2006). Assessing Change in Perceived Organizational Support Due Training. Paper Presented at the 21st Annual Conference of the Society For Industriasl and Organizational Psychology. Journal of Organizational Behaviour. 8(3),71-80.

Nazir, O., dan Islam, J.U. (2017). Enchancing organizational commitment and employee perfromnce through employee engagement (An empirical check). Shout Asian Journal of Business Studies. 6(1), 98-144

Nur'aini. (2012). Pengaruh Perceived Organizational Support Terhadap Kinerja Karyawan Dengan Employee Engagement Sebagai Variabel Intervening. Jurnal Manajemen. 2(6), 18-26

Pathak, Depti. (2012). Role of perceived organizational support on stresssatisfaction relationship: An empirical study. Asian Journal Of Management Research, $3(1), 88-95$.

Puspita. N.M.D., dan Riana, I Gede. (2014). Pengaruh Kepuasan Kerja terhadap Komitmen Organisasional dan Kualitas Layanan. Jurnal Manajemen Strategi Bisnis dan Kewirausahaan, Vol. 8, No. 1.

Rahmi, Fitria., dan Riyono, Bagus.(2016).PengaruhKarakteristikPekerjaan terhadap Perilaku Kewargaan Organisasi dengan Mediator Nilai-nilai Kualitas Kehidupan Kerja. Jurnal Psikologi Undip, Vol. 15, No. 1.

Rayton, B.A., \& Yalabik, Z.Y. (2014). Work engagement, psychological contract breach and job satisfaction. The International Journal of Human Resource Management,25(17),2382-2400.

Rhoades, Eisenberger. (2002). Perceived Suppervisor Support: Contributions to Perceived Organizational Support and Employee Retention. Journal of Applied Psychology, 87(3), 565-571

Rhoades, L., Eisenberger, R., \& Armeli, S. (2001). Affective commitment to the organization: The contribution of perceived organizational support. Journal of Applied Psychology, 86(4), 825-836.

Robbins, S dan Timothy, A.J. (2008). Perilaku Organisas. Buku 2. Edisi 12. Jakarta: SalembaEmpat.

Rousseau, M.D. (2000). Psychological Contract Inventory Technical Report.Heinz School of Public Policy and Graduate School of Industrial Administration. Journal Carnegie Mellon University Pittsburgh.2(6), 231-246.

Sharma, J., \& Dhar, Rajib L. (2016). Factors influencing job performance of nursing staff Mediating role of affective commitment. Job performance of nursing staff, 45(1), 161-182. 
Shaun Tyson. (2006). Essentials of Human Resource Management. United Kingdom Kopar Rage.

Solimun, Fernandes, A. A. R., \& Nurjannah. (2017). Pemodelan Persamaan Struktural(SEM)Pendekatan Warp PLS. UB Press:Malang.

Sopiah (2008).Perilaku Organisasi. Edisi Pertama, Yogyakarta: Andi

Sugiyono (2017). Metode Penelitian Kuantitatif Kualitatif dan R\&B. Bandung: CV. Alfabet

Tsui, P. L. (2013). The Influence Of Psikological Contract and Organizational Commitment On Hospitality Employee Performance. Social Behavior and Personality, 2(3), 443-452.

Van den Heuvel, S., Schalk, R., \& Van Assen, M.A. (2015). Does a well-informed employee have a more positive attitude toward change? The mediating role of psychological contract fulfillment, trust, and perceived need for change. The Journal of Applied Behavioral Science, 51(3), 401-422.

Wayne, Sandy J Shore, Lynn M., Bommer, William H., Tetrick, Lois E., (2002). The role of fair treatment and reward in perceptions of organizational support and leader-member exchange. Journal of Applied Psychology, 4(5), 390-598.

Widarianti, I, G.A.R dan Sintaasih, D.K. (2019). Pengaruh Kepemimpinan trasformasional dan kepuasan kerja terhadap komitmen organisasional karyawan. E-Jurnal Manajemen, 8(10), 6242-6261.

Wijaya, N.A., dan Yuniawan, A. (2017). Organisasi terhadap Organizational Citizenship Behavior dengan Komitmen Organisasi sebagai Variabel Intervening (Studi pada Karyawan bagian antaran PT . Pos Indonesia Processing Center Semarang), Vol6, No 1-15.

Wirawan, Nata. (2014). Cara Mudah Memahami Stastika Ekonomi Dan Bisnis (Statistika Inferensi).Edisi ketiga. Keraras Emas, Bali. 